University of Wollongong

Research Online

Faculty of Business - Papers (Archive)

Faculty of Business and Law

$1-1-2017$

The links among characteristics, controls and performance of inter-firm innovation projects

Maria Cadiz Dyball

University of Sydney

Andy Wang

Australian Catholic University, andywang@uow.edu.au

Follow this and additional works at: https://ro.uow.edu.au/buspapers

Part of the Business Commons

Research Online is the open access institutional repository for the University of Wollongong. For further information contact the UOW Library: research-pubs@uow.edu.au 


\title{
The links among characteristics, controls and performance of inter-firm innovation projects
}

\begin{abstract}
This study aims to explore the effects of: (1) the project characteristics of asset specificity, uncertainty and complexity on the performance of, and, the use of formal and social controls in inter-firm innovation projects, and, (2) the use of formal and social controls on the performance of inter-firm innovation projects. In addition, the mediating role of the use of formal and social controls in the relationships between the characteristics and performance of inter-firm innovation projects is also examined. Survey data from 75 organisations in innovation-active industries in Australia were analysed using the structural equation modelling with the Partial Least Square technique. The results show that uncertainty and complexity affected performance of inter-firm innovation projects, but in opposite directions. Higher levels of uncertainty were associated with less use of social controls but higher levels of complexity were partnered with a greater use of both formal and social controls. The use of formal and social controls individually impacted on inter-firm innovation project performance. Finally, the use of formal and social controls played a partial mediating role in the relationships of uncertainty and complexity with inter-firm innovation performance. Responding to gaps in research, this study clarifies that asset specificity may be irrelevant whilst uncertainty and complexity may be highly relevant in the performance of, and, the use of controls in inter-firm innovation projects. The study offers valuable insights into how a complementary use of controls contributes to the performance of inter-firm innovation projects.
\end{abstract}

\section{Keywords}

projects, performance, inter-firm, controls, characteristics, links, innovation, among

\section{Disciplines}

Business

\section{Publication Details}

Dyball, M. Cadiz. \& Wang, A. Fengfei. (2017). The links among characteristics, controls and performance of inter-firm innovation projects. International Journal of Innovation Management, 21 (6), 1850015-1-1850015-33. 


\title{
The links among characteristics, controls and performance of inter- firm innovation projects
}

\begin{abstract}
This study aims to explore the effects of: 1) the project characteristics of asset specificity, uncertainty and complexity on the performance of, and, the use of formal and social controls in inter-firm innovation projects, and, 2) the use of formal and social controls on the performance of inter-firm innovation projects. In addition, the mediating role of the use of formal and social controls in the relationships between the characteristics and performance of inter-firm innovation projects is also examined. Survey data from 75 organizations in innovation-active industries in Australia were analysed using the structural equation modelling with the Partial Least Square technique. The results show that uncertainty and complexity affected performance of inter-firm innovation projects, but in opposite directions. Higher levels of uncertainty were associated with less use of social controls but higher levels of complexity were partnered with a greater use of both formal and social controls. The use of formal and social controls individually impacted on inter-firm innovation project performance. Finally, the use of formal and social controls played a partial mediating role in the relationships of uncertainty and complexity with inter-firm innovation performance. Responding to gaps in research, this study clarifies that asset specificity may be irrelevant whilst uncertainty and complexity may be highly relevant in the performance of, and, the use of controls in inter-firm innovation projects. The study offers valuable insights into how a complementary use of controls contributes to the performance of inter-firm innovation projects.
\end{abstract}

Keywords: asset specificity; uncertainty; complexity; formal controls; social controls; inter-firm innovation project performance. 


\section{Introduction}

Innovation is a process whereby organizations transform ideas into new or improved products, service or processes in order to advance, compete and differentiate themselves successfully in the marketplace (Baragheh, et al., 2009; Dodgson et al., 2002). Innovation may be more severe and difficult to control than other organizational processes and transactions because of its characteristics of newness and change (Kerssens-van Drongelen and Bilderbeek, 2009; Zhao, 2003). It is about "taking advantage of exceptions; experimenting, failing and succeeding; uncertainty and volatility; inefficiencies; adapting to unforeseen opportunities; and foremost creativity" (Davila et al., 2009, p.285). Whilst innovation has typically been seen to occur within the boundaries of an organization, the manner in which many organizations innovate has changed as it has moved from a closed to an open process (Bigliardi et al., 2010; Chesbrough, 2003). Through inter-firm innovations, organizations actively cooperate with external actors to compensate for their scarce internal resources and limited competencies (Lichtenthaler, 2008; Baum et al., 2000).

But inter-firm collaborations expose firms to risks of appropriation and performance (Rosell, 2014; Das and Teng, 2001). The reliance on external parties can be problematic because key areas of expertise of a collaborator may be gradually appropriated by the other partner. One might also discover that a partner does not have the competency to ensure a successful innovation outcome. Arguably, inter-firm innovations are generally higher risk projects than intra-firm innovations and other types of inter-organizational collaborations. They present a paradox for organizations and scholars: while one wants to actively cooperate to transform ideas into cutting-edge or better products, services or processes, one also must guard against the possibility that expertise and competitive advantage may be lost. Crucially, the benefits gained from engaging in inter-firm innovation projects do not accrue automatically but require 
conscious management action (Mohr and Sengupta, 2004). According to Crossan and Inkpen (1995), maximizing the value of inter-firm innovation necessitates that organizations put in place suitable control mechanisms. Controls help minimize appropriation and performance risks (Miller et al., 2011; Hoecht and Trott, 2006) by creating ample space for both the 'firmness and flexibility' required in inter-firm innovations (van der Meer-Kooistra and Scapens, 2008). They also assist in coordinating interdependent tasks (Rosell, 2014; Dekker, 2004), which are characteristic of inter-firm innovations. Notably, there are few studies that have investigated the use of controls to manage the dual challenge of cooperation and coordination in inter-firm collaborative innovation projects (Rosell, 2014). The lack of research may be reflective of a view in the innovation management literature that formal management control mechanisms constrain, or at worst are irrelevant to, product development (e.g. Verona, 1999; Dougherty and Hardy, 1996). However, there has been a growing acknowledgement that successful innovations require organizational mechanisms (Bharadwaj and Menon, 2000). There are scholars like Hansen and Jönsson (2005), and, Davila (2000) who propose that formal control mechanisms could enable innovation. Mouritsen et al. (2009) for instance, suggest that these control mechanisms encourage and ensure that innovation projects are aligned with the strategic intent of organizations.

This study draws from the theory of transaction cost economics to begin to identify that the project characteristics of asset specificity, uncertainty and complexity are highly relevant in helping understand how to manage appropriation and performance risks in inter-firm innovations (see Williamson, 1985). This study also adopts a contingency-based framework to propose links between these characteristics, on the one hand, and the use of controls in, and, performance of inter-firm projects, on the other hand. A contingency framework implicates contextual variables in the design of effective controls and performance. This framework can be traced to the original structural contingency frameworks developed within 
organizational theory (Chenhall, 2006). According to Chenhall (2006, p.164), theorists such as Burns and Stalker (1961), Perrow (1970), Thompson (1967), Lawrence \& Lorsch (1967) and Galbraith (1973) focused on the impact of environment and technology on organizational structure. Early accounting researchers then drew on this work to investigate the importance of environment, technology, structure and size to the design of management control systems. This study adopts this approach to link risk factors with management control mechanisms and project performance.

This study seeks to address areas which have received minimal attention so far, including firstly how risk factors influence the use of controls in, and, performance of inter-firm innovation projects (McCarthy and Gordon, 2011; Dekker, 2004). The second gap is identified by Ding and colleagues (2013) who observed there are only a few studies that examine the link between management controls and inter-firm collaboration performance. Finally, this study seeks to address the equivocal position in the literature on the individual effects of two types of management controls namely, formal and social controls, on innovation performance (Bisbe and Otley, 2004).

This study thus has two aims. The first aim is to examine the impact of inter-firm innovation project risks, operationalized as asset specificity, uncertainty and complexity, on the use of formal and social controls in, and the performance of, inter-firm innovation projects. The second aim is to assess the influence of formal and social controls on innovation project performance. The study contributes to the literature on the management of inter-firm innovation projects in two ways. Firstly, it fosters a deep understanding of the link between innovation project characteristics which indicate risks, on the one hand, and the use of controls and inter-firm innovation project performance, on the other hand (Davila et al., 2009). According to Gasmann (2006), the opening up of the innovation process requires adaptation of management systems. The focus on inter-firm innovation at a project level 
instead of at an organizational level is salient because of the temporal nature of projects. Projects are claimed to require more interpersonal and less formal processes of coordination (Janowicz-Panjaitan et al., 2009). Interestingly, the same view on the use of controls in temporal projects can be applied to the management of innovation risks, where it is argued that the use of formal controls is less suitable but more amenable to the use of social controls (Hoecht and Trott, 2006). Secondly, the study tests an under investigated postulate that the use of management controls contribute to better performance of inter-firm collaborations (Dekker et al., 2013; Ding et al., 2013). Thus, the study also explores consequences of the use of inter-firm innovation controls on performance.

The remainder of the paper has 4 sections. Section 2 presents the literature review and hypotheses development. Sections 3 and 4 provide the research method and findings. Section 5 concludes with a discussion of the implications of the findings, limitations of the study and areas for further research.

\section{Literature review and hypotheses development}

\subsection{Project characteristics of asset specificity, uncertainty and complexity, and, project performance}

This study draws on the theory of transaction cost economics (TCE) to highlight the risks that inter-firm innovation projects have. TCE focuses on the potential downsides of cooperation while the resource-based view of the firm emphasizes the upside of cooperation (Finch et al., 2015). Crucially, TCE adopts a passive risk management perspective with a focus on pre-calculation of risk arising from partners' opportunistic behaviours and bounded rationality (Anderson and Dekker, 2009). In so doing, it allows a considered response to the question of how organizations could manage the paradox of inter-firm innovations.

Drawing from TCE and studies that have adopted TCE and contingency theory, this study 
identified three project properties namely asset specificity, uncertainty and complexity of transactions as potentially helping explain the appropriation and performance risks of interfirm innovation projects (Dekker, 2004; Williamson, 1985). It is worth noting that while TCE lists asset specificity and uncertainty, it also includes the factor of frequency. The innovation literature, however, characterizes the innovation process with uncertainty and complexity (Triguero and Córcoles, 2013). Moreover, the definitions and operationalization of the construct of uncertainty in the accounting and innovation literatures are not identical and overlap with those of frequency, as defined by TCE, and, complexity. In the accounting literature uncertainty is linked to the environment and technology (Ditillo, 2004). Various authors then include and place differing emphases on elements of dynamism, heterogeneity, predictability and controllability in regard to environmental uncertainty, and, on task uncertainty, complexity and interdependence when referring to the degree of technological uncertainty. In the innovation literature a common definition of complexity is in the anthropological sense of increasing differentiation and specialization in structure combined with increasing integration of parts (Tainter, 1988). In light of the overlaps and varied emphases in definitions, this study examines the factors of asset specificity and uncertainty as operationalized and used in the accounting literature (and drawing from TCE), and complexity as generally understood in the innovation literature (noting definitional overlaps with TCE). Particularly on uncertainty, it is the element of predictability of the environment which is the interest of the study.

Asset specificity relates to the dedicated investments in inter-firm innovation projects. As noted by Langfield-Smith (2008, p.346) who referred to the work by Williamson (1991) and Nooteboom (2004), asset specificity can take several forms: site or location specificity, physical assets specificity, human assets specificity (training, knowledge), brand name or reputational capital, and dedicated capacity. A high degree of asset specificity signifies 
little alternative use of these investments outside the project resulting in a high level of bilateral dependency between parties (David and Han, 2004). It also results in a heightened level of appropriation risk by the partner, which could then severely impact on the performance of innovation projects (Dekker, 2004). Appropriation risk is explained by TCE as emanating from opportunistic partners who will pursue their self-interests.

A high level of uncertainty translates into a low level of predictability of the market and customer technical requirements of inter-firm innovation projects. Higher uncertainty implies that inter-firm innovation teams will find it more difficult to design a product, service or process that will satisfy market requirements. In addition to being self-interested and opportunistic, TCE also depicts human beings as having bounded rationality. Economic decision-making whilst intentionally rational is limited by "experience cognitive constraints", which include limited information, lack of knowledge and informationprocessing capabilities (Vosselman \& van der Meer-Kooistra, 2006). The higher level of unpredictability and the limited ability of partners to effectively deal with it, reduces the likelihood that the innovation project will succeed in the market or in its implementation in an organization resulting in poorer project outcomes (Tatikonda and Rosenthal, 2000), that is, performance risk.

Complexity is explained in terms of novelty of the technology (Carbonell and Rodriguez, 2006), the number and level of skills required, and the extent of integration and interaction involved with the skills and functions (Chapman and Hyland, 2004). Practitioners describe an innovation project as having a high level of technology risk when, at the beginning of the project, they do not fully understand the technology, hence do not know the exact means to accomplish the project (Tatikonda and Rosenthal, 2000). This is expected using TCE as a framework because human actors are assumed to have bounded rationality. Hence the newness of technology conflates task uncertainty resulting in a high 
probability of negative task outcomes. But Tatikonda and Rosenthal (2000) found that that use of higher levels of new technology actually results in greater achievement of the innovation performance objectives. They attribute this finding, in regard to new product developments, to firms often under anticipating the technical performance capabilities of new technology employed to develop a new product. As for other factors impacting on complexity, the extent of integration and interaction involved with the skills and functions are also depicted as contributing to task uncertainty resulting in unsatisfactory project outcomes, in particular development times or time-to-market (Griffin, 1997; Meyer and Utterback, 1995). Hence overall we propose the following set of hypotheses:

Hla. Asset specificity is negatively associated with the performance of inter-firm innovation projects.

$H 1 b$. Uncertainty is negatively associated with the performance of inter-firm innovation projects.

Hlc. Complexity is negatively associated with the performance of inter-firm innovation projects.

2.2 Project characteristics of asset specificity, uncertainty and complexity, and, the use of formal and social controls

Researchers seem to accept that innovation is a phenomenon that can be subjected to human control perhaps because it is considerably affected by human interaction (Hoecht and Trott, 2006). The discussion in this section takes both a TCE and a contingency approach to link the project characteristics of asset specificity, uncertainty and complexity with the use of management control mechanisms. Management controls are said to minimize innovation risks (Han et al., 2008) and are important in maintaining and developing inter-firm collaboration (Kang et al., 2014). They are designed to assist collaborating organizations to regulate themselves (Otley et al., 1995) in uncertain settings (Gordon and Narayanan, 1984). Indeed Simons (1987) found that organizations that pursued innovation and growth significantly used various control systems than those that did not. Henri (2006) and 
Bisbe and Otley (2004) thereafter demonstrated that the interactive use of formal controls impacted on organizational capabilities to innovate and on organizational performance.

Management control systems are defined as a set of different procedures and processes to ensure achievement of management and organizational goals (Otley and Berry, 1994). These systems provide information which can be used for decision making, planning, controlling and evaluation (Merchant and Otley, 2007). Controls have been categorized as formal and informal controls (Kirsch, 1997; Anthony et al., 1989); output and behavior controls (Ouchi, 1977); market, bureaucracy and clan controls (Ouchi, 1979); administrative and social controls (Hopwood, 1976), and results, action and personnel controls (Merchant, 1985). In this study controls are categorized as formal and social controls, a classification used in studies of Australian inter- firm collaborations, a context shared here (Giacobbe and Booth, 2009; Langfield-Smith, 2008; Mahama, 2006). Formal controls specify contractual obligations and explicitly designed organizational mechanisms to manage inter-firm collaboration (Dekker, 2004; Langfield-Smith and Smith, 2003). They help organizations and their members focus on final outcomes and prescribe the appropriate behavior to achieve these outcomes (Vélez et al., 2008; Dekker, 2004; Das and Teng, 2001). Social controls cover informal cultures and systems, communication, socialization and self-regulation (Mahama, 2006; Dekker, 2004). They assist in increasing relationship commitment, reducing goal incongruence and establishing a compatible set of values between collaborating partners (Mahama, 2006; Das and Teng, 2001). According to relationship marketing theory, there should be facilitative mechanisms to help collaborators develop a competence in managing inter-organizational relationships. Simonin (1997), for instance, states that learning how to collaborate assists in successful relationships. In this study, the use of social controls provides a means for partners to engender a commitment to 
the relationship, which then results in the collaborators increasing the likelihood of positive project outcomes.

As indicated earlier, a high degree of asset specificity signifies little alternative use of resources beyond the project leading to parties being highly dependent on each other (David and Han, 2004). This scenario exemplifies the inter-firm innovation paradox for organizations and scholars. The use of resources including human assets (training, knowledge) solely for an inter-firm innovation project is equated with a situation where a party will be accorded exclusive access to the other party's highly specialized expertise thereby potentially fulfilling an aim of inter-collaborative projects of gaining new or better expertise. However, according to TCE, this exclusive access to highly specialized resources also creates appropriation risk.

The potential risk triggers a safeguarding of investments through controls. According to TCE, the bounded rationality of partners results in incomplete contracts and formal controls. So while formal controls may be useful, on their own they are insufficient to mitigate appropriation risk. Hence, social controls must be used in conjunction with formal controls to allow further monitoring and curbing of the partner's potential opportunistic behavior arising from a high degree of asset specificity (Gulati and Singh, 1998). In addition the role of social controls in encouraging a commitment to the relationship means that efforts will be expended to achieve project outcomes.

Uncertainty also presents a challenge for rational decision-making. Further, unpredictability of market and customer technical requirements means that it will be difficult to establish clear specifications, goals and outcomes (Kang et al., 2014; Dekker, 2004), thus presumably resulting in reliance on both formal and social controls. Contracts, as earlier noted, are inherently incomplete not only because of the bounded rationality of contracting parties but also because of environmental and technological uncertainty. These two factors 
combine to create contracts that cannot pre-specify every future contingency. Arguably, innovations, which require adapting to many unforeseen opportunities and challenges (Davila et al., 2009), are imbued with compounded uncertainty. This characteristic of innovations make the use of contracts useful (Dekker, 2004) but if used solely may be ineffective in dealing with uncertainty. Van der Meer-Kooistra and Scapens (2015) identify the need for a social structure to compensate for the limitations of incomplete contracts and other formal modes of control. A social structure is concerned with the day-to-day activities of the innovation process and includes team-based structures and regular meetings which enable collaborating parties to communicate with each other. Information sharing allows parties to make sense of an unpredictable context (Revilla and Knoppen, 2015). In addition, Speklé (2001) advises that when confronted with high uncertainty, firms through the use of social controls, strive to establish a situation of commitment and congruency to achieve desired outcomes. The push to create commitment from transacting parties is also necessary to counter their opportunistic and self-interested tendencies. Thus overall, in conditions of high uncertainty, successful organizations use a combination of formal and social controls (Chenhall and Morris, 1995).

In a comprehensive review of literature on management control systems in innovation companies, Haustein et al. (2014) deduce that in conditions of a high level of complexity, it will become very difficult to express the outcome of transformation processes in numbers. An impersonal mode of coordination by rules, procedures, plans and schedules may be challenging to implement (Abernethy and Brownell, 1997; Chapman, 1997; Van de Ven et al., 1976). Indeed, Van de Ven et al. (1976) propose that more personal and group- based modes of coordination will also be required. Despite their opportunistic leanings, employees need to be fully committed to their specific roles (Wilkins and Ouchi, 1983), and, social controls that focus on communication and participative decision-making enhance 
opportunities for creativity and the free flow of ideas particularly because there is a variety of skills and functions involved (Burns and Stalker, 1961). Social controls resulting in effective communication also allows the sharing of domain specific knowledge (e.g., knowledge about technology) (Rundquist, 2012).

Indeed Dekker (2004) drawing from Borys and Jemison (1989), does not think that organizations should choose between formal or social controls. Instead he proposes that a higher level of interdependence requires more sophisticated coordination mechanisms than that of a set of a low level of formal controls and a high level of social controls. In Dekker's case, interdependence is a function of the number of skills required, and the extent of integration and interaction involved with the skills and functions. His findings resonate in this study because these elements partly determine the level of complexity of innovation projects. He finds in his research that a combination of formal and informal control mechanisms was mobilised. The former included budgeting and performance evaluation and measurement, and, the latter involved joint interaction and problem solving, and, communication. Hence we propose the following set of hypotheses:

$H 2 a$. Asset specificity is positively associated with the use of formal controls in inter-firm innovation projects.

$H 2 b$. Asset specificity is positively associated with the use of social controls in inter-firm innovation projects.

$H 2 c$. Uncertainty is positively associated with the use of formal controls in inter- firm innovation projects.

$H 2 d$. Uncertainty is positively associated with the use of social controls in inter- firm innovation projects.

H2e. Complexity is positively associated with the use of formal controls in inter-firm innovation projects.

$H 2 f$. Complexity is positively associated with the use of social controls in inter-firm innovation projects.

2.3 The use of formal and social controls, and, performance 
Formal controls help ensure that innovative ideas are translated into effective innovations and enhance performance (Chenhall and Morris, 1995). However, they are also viewed as incompatible with innovation because they can deter creativity and may not be able to adequately cope with the uncertainty inherent in innovations (Amabile, 1998). But formal controls do coexist with innovation (Ezzamel, 1990). Notably, the most innovative firms are intensive users of formal controls (Simons, 1995). In regard to social controls, Hoecht and Trott (2006) posit that they are more effective than formal controls in managing innovation risks. The social interconnectedness in inter-firm innovation relationships (Baraldi and Strőmsten, 2009) highlights the primacy of people in innovation success and therefore the need for more communication to cultivate commitment (Soutar and McNeil, 1993), helping improve innovation performance (Rundquist, 2012). Thus overall, different types of controls perform specific roles in helping attain success in inter-firm innovation (Davila, 2005). Hence, the use of a combination of controls is proposed as being more effective in achieving innovation goals than the use of a single type of control (Chen et al., 2009). In the case of intra-firm innovations, Bisbe and Malagueño (2009) make a similar observation that an organization's ability to either curb innovation excesses or encourage innovativeness may depend on the activation of diverse forms of control, to create a complementary fit. Therefore the following set of hypotheses is proposed:

$H 3 a$. The use of formal controls is positively associated with the performance of inter-firm innovation projects.

$H 3 b$. The use of social controls is positively associated with the performance of inter-firm innovation projects.

\subsection{The mediating effect of formal and social controls}

The set of hypotheses from $\mathrm{H} 2 \mathrm{a}$ to $\mathrm{H} 2 \mathrm{f}$ suggests a direct link between asset specificity, uncertainty and complexity, on the one hand and the use of formal and social controls, on the 
other hand. $\mathrm{H} 3 \mathrm{a}$ and $\mathrm{H} 3 \mathrm{~b}$ also predict a positive link between the use of formal and social and inter-firm innovation projects performance. Hence overall these hypotheses suggest a mediating role for the use of formal and social controls in the proposed link between the characteristics and performance of inter-firm innovation projects as captured in the first set of hypotheses $(\mathrm{H} 1 \mathrm{a}-\mathrm{H} 1 \mathrm{c})$. Therefore, collectively the following hypotheses are proposed:

H4a. The relationship between asset specificity and the performance of inter-firm innovation projects is mediated by the use of formal controls.

$H 4 b$. The relationship between uncertainty and the performance of inter-firm innovation projects is mediated by the use of formal controls.

$H 4 c$. The relationship between complexity and the performance of inter-firm innovation projects is mediated by the use of formal controls.

$H 4 d$. The relationship between asset specificity and the performance of inter-firm innovation projects is mediated by the use of social controls.

$H 4 e$. The relationship between uncertainty and the performance of inter-firm innovation projects is mediated by the use of social controls.

H4f. The relationship between complexity and the performance of inter-firm innovation projects is mediated by the use of social controls.

The conceptual model is presented in Figure I below:

[Insert Figure 1 here]

\section{Research method}

Data were collected through a self-administrated paper-based survey from a sample of senior managers who acted as primary liaison officers for organizations engaged in interfirm innovations. The targeted organizations were randomly selected from large companies $^{1}$ in OneSource database from the wholesale trade, retail trade, information

\footnotetext{
${ }^{1} \mathrm{~A}$ large company is defined as one that meets at least one of three criteria: (1) having revenue for the financial year that is $\$ 25$ million or more; (2) having gross assets with a value of $\$ 12.5$ million or more of at the end of the financial year; (3) having 50 or more employees at the end of the financial year.
} 
media and telecommunications, professional, scientific and technical services and manufacturing industries. More than $45.2 \%$ of businesses in these industries were reported as innovation-active businesses in the 2010-11 Innovation in Australian Business Survey (IABS) (Australian Bureau of Statistics, 2013). To ensure that we sent the questionnaires to relevant organizations and knowledgeable staff and therefore improve the quality of responses, telephonic recruitment was undertaken to identify potential survey respondents. The final sample of survey participants met the criteria of their organizations having been involved in at least one inter-firm innovation in the last three years, of being the knowledgeable staff, and, expressing interest in participating in the study. As a result, 317 questionnaires were distributed and 75 valid responses were received. Thus, the final response rate is $24 \%$.

As reported in Table $1,66 \%$ of the respondents were members of top management, including CEOs, CFOs and directors, and $31 \%$ were functional managers, such as general managers and operations managers. Majority $(65 \%)$ of the respondents had worked with the organization for more than 10 years.

\section{[Insert Table 1 here]}

\subsection{Instrument design}

To fine-tune the instrument, a pilot test was conducted with three expert academics resulting in minor modifications to the survey instrument. ${ }^{2}$ All items on the constructs of asset specificity, uncertainty and complexity were measured using a seven-point Likert scale ranging from $1=$ very low to $7=$ very high. For measurement of formal and social controls, the respondents were asked to rate their use of these controls on a seven-point Likert scale with $1=$ never used to $7=$ often used. Innovation performance was also measured on a

\footnotetext{
${ }^{2}$ The survey instrument is available upon request from the corresponding author.
} 
seven-point Likert scale ranging from $1=$ strongly disagree to $7=$ strongly agree. A summary of all variables descriptions is provided in an Appendix.

Asset specificity was measured using six items which were adapted and modified based on Dekker (2008), Geyskens et al. (2006), and Heide and John (1990). ${ }^{3}$ The respondents were asked to rate the degree in which human capital (e.g. training, knowledge), brand name, equipment and other physical assets, site or facilities, tailored procedures and routines can be redeployed outside a particular innovation. If the possibility of redeployment is high, there is low asset specificity. Consistent with extant literature, the measurement items consists of human assets specificity (training, knowledge), brand name or reputational capital, physical assets specificity, site or location specificity, and dedicated capacity (Langfield-Smith, 2008). They all relate to transaction-specific assets used for an innovation project (Geyskens et al., 2006). All the items are well above the cut-off of 0.50 suggested by Bisbe and Otley (2004) and one factor solution can explain 59.23\% of common variance for this construct.

Uncertainty is defined as the inability of the firm to accurately forecast the external environment, technical requirements, and market and industry changes in the context of a particular inter-firm innovation, which captures the elements of environmental, technological and behavioral uncertainties suggested by Geyskens et al. (2006). There were seven items, which were adapted and modified from Dekker (2008), Geyskens et al. (2006), and Heide and John (1990). All seven items loaded well on one factor and explained $64 \%$ of common variance for uncertainty.

Complexity measures the degree of the newness of the technology (technological

\footnotetext{
${ }^{3}$ One global indicator was also used for all reflective constructs to test the correlation of individual items to this global item. The results showed high levels of correlation between individual and global items. The global items were excluded during the structural model analysis.
} 
complexity), the number and level of skills or functions required, the extent of interactions among different skills or functions (organizational complexity), and the extent of integration required (development complexity). There were seven items adapted from Dekker (2008), and, Kim and Wilemon (2003). Factor analysis revealed that all items loaded on a single factor with $66.75 \%$ common variance explained.

The use of formal and social controls was measured as two formative constructs, as these two variables consist of different "inherent constitutive facets" (Bisbe et al., 2007) of control mechanisms. Most of the indicators used to measure these two constructs were based on Giacobbe and Booth (2009), Kamminga and van der Meer-Kooistra (2007), and Chalos and O'Connor (2004). Formal controls consist of contracts, planning and budgeting, standardised procedures and rules, formal project methodology (e.g. PRINCE2, PIMBOK, AGILE, SCRUM), performance evaluation and management reports. Social controls include networking and other socialization processes, teams and taskforces, rituals, traditions and ceremonies, organizational culture/values alignment, face-to-face communication and participatory decision-making. The respondents were asked to indicate the extent to which these control mechanisms were used by their organizations to manage a particular inter-firm innovation project.

Inter-firm innovation project performance captures the degree to which the goals were achieved, articulated as: achieving the primary objective, enhancing the organization's competitive position, learning some critical skill(s) or capabilities, and exhibiting higher innovation performance compared to competitors. Five items were adapted from Walter et al. (2008). $72.966 \%$ of common variance was explained by a one factor construct.

\subsection{Control variables}

To improve the explanatory power of the proposed path models, a number of variables 
were controlled for the analysis, including sector of the company, size of the company, innovation types ${ }^{4}$, stage of inter-firm innovation, ownership of inter-firm relationship, and, prior experience ${ }^{5}$ with this partner (Chiesa et al., 2009; Davila et al., 2009; Dekker, 2008; Luo, 2008) (see Table II). These control variables were used during data analysis as moderating variables for the structural models.

\section{[Insert Table 2 here]}

\subsection{Tests for potential biases}

To test for non-response bias, late responses were compared with early responses by using t-tests on all the measurements. No significant differences were found, thus, nonresponse bias does not appear to be a concern in the study. To test for the potential of social desirability bias, Shapiro-Wilk tests of normality were conducted. The results indicated normal distributions and considerable variances in responses for the variables of interest. To minimise the likelihood that the respondents provided socially desirable answers to the questions, information about anonymity was provided in the cover letter and questionnaire. Thus, reasonable steps and tests were undertaken to minimize and detect social desirability bias from the respondents. Potential common method bias seems also not a concern based on Harman's (1967) single-factor test with results showing that no single factor explains the majority of variance (Dowling, 2009).

\section{Results}

Data analysis was conducted by using the structural equation modelling (SEM) with the Partial Least Square (PLS) technique (Chin, 1998), which is a component-based SEM

\footnotetext{
${ }^{4}$ Three questions collected information on the nature of innovation and the degree of inter-firm innovation. ${ }^{5}$ We use the stage of innovation as a proxy of the duration of inter-firm relationship and prior experience as an indicator of relationship closeness.
} 
technique for analysis of research models with both reflective and formative constructs (Gefen and Straub, 2005). The software SmartPLS Version 3.0 was used (Ringle et al., 2015).

\subsection{Measurement models}

Reflective constructs were tested for internal consistency reliability, convergent and discriminant validities. As illustrated in Table III, both Cronbach alpha and composite reliability scores are above the 0.70 suggested benchmark for internal consistency of a reflective construct (Chin, 1998). To assess convergent validity, confirmatory factor analysis (CFA) was performed by PLS (Davis et al., 2014). Factor loadings for all retained items are well above the cut-off of 0.50 and all significant on the intended construct $(p<0.001)$. In addition, average variance extracted (AVE) for these constructs exceed the suggested value of 0.50 , which also suggests a high level of convergent reliability (Chin, 1998). Discriminant validity of reflective constructs was assessed based on factor cross-loading and the square root of the AVE statistics. As shown in Tables IV and $\mathrm{V}$, all items loaded higher on their own construct than other constructs both horizontally and vertically, and each construct shares more variance with its own items than other constructs, i ndicating an acceptable degree of discriminant validity (Davis et al., 2014, Lau and Roopnarain, 2014; Chin, 1998).

[Insert Tables 3, 4 and 5 here]

As the use of formal and social controls was measured as formative constructs, common construct validity tests cannot be applied (Petter et al., 2007). As recommended by Petter et al. (2007), indicators weights were examined though principal component analysis. All of the formative indicators have significant weights at $p<0.001$ level. To 
assess the potential problem of multicollinearity, variance inflation factor (VIF) analysis was conducted in SPSS 20 by regressing each indicator on the other indicators of formative constructs (Davis et al., 2014). The results show all VIF scores are below the cut-off value of 3.3, which means that multicollinearity is not a problem with the formative constructs (Davis et al., 2014; Petter et al., 2007).

\subsection{Structural models}

The structural models were tested by bootstrapping techniques with 1,000 samples replacement (Hartmann and Slapničar, 2009). As presented in Figures $2, R^{2}$ values for the use of formal controls, the use of social controls and inter-firm innovation performance range from 0.356 to 0.530 , which indicate sufficient explanatory power (Chin, 1998).

As shown in Figure 2, the results show that there is no significant association between asset specificity and innovation performance $(\mathrm{H} 1 \mathrm{a})$, however significant negative association $(p<$ 0.01) exists between uncertainty and innovation performance (H1b), and, significant positive association $(p<0.001)$ is identified between the level of complexity and innovation performance $(\mathrm{H} 1 \mathrm{c})$. Hence, this study provides evidence to support $\mathrm{H} 1 \mathrm{~b}$ and evidence for an opposite positive relationship to H1c. The results also reveal that the paths between asset specificity and the use of formal and social controls are insignificant. Hence, H2a and $\mathrm{H} 2 \mathrm{~d}$ are not supported. There was also no significant association found between uncertainty and the use of formal controls $(\mathrm{H} 2 \mathrm{~b})$. The path between uncertainty and the use of social controls, however, is significant $(p<0.05)$, but the co-efficient is -0.170 , which suggests a negative association between the level of uncertainty and the use of social controls. Thus, $\mathrm{H} 2 \mathrm{c}$ is also not supported but results suggest an opposite negative association. The paths between complexity on the one hand and the use of formal controls $(p<0.001)$, and, social controls $(p<0.01)$, on the other hand, are both statistically 
significant. $\mathrm{H} 2 \mathrm{c}$ and $\mathrm{H} 2 \mathrm{f}$ are therefore supported. The results also show strong positive associations between the use of both formal and social controls and inter-firm innovation performance $(p<0.01, p<0.001)$, providing evidence to support H3a and H3b.

\section{[Insert Figure 2 here]}

$\mathrm{H} 4 \mathrm{a}-\mathrm{H} 4 \mathrm{f}$ predict that the use of formal controls and social controls mediates the relationships between asset specificity, uncertainty and complexity on one hand, and the performance of inter-firm innovation on the other hand. Additional tests were performed to examine potential mediation effects following Baron and Kenny (1986). Two submodels are analyzed using the use of formal and social controls as mediators. As shown in Figure 2, the direct model, using transaction characteristics (asset specificity, uncertainty and complexity) as independent variables and inter-firm innovation project performance as dependent variable, reveals that uncertainty is negatively associated with innovation performance $(\beta=-0.352, \mathrm{t}=3.110, p<$ $0.01)$ and complexity is positively associated with innovation performance $(\beta=0.380, \mathrm{t}=$ $3.481, p<0.001)$. When the use of formal controls is added as mediator, Table 6 shows that the direct path coefficients for both uncertainty and complexity to performance are still significant $(\beta=0.319, \mathrm{t}=2.314, p<0.05 ; \beta=0.257, \mathrm{t}=2.065, p<0.05)$. Following Baron and Kenny (1986), the results suggest partial mediations only for the use of formal controls. This is observed because the relationships between both uncertainty and complexity to performance remain significant after the use of formal controls is introduced as a mediator in these relationships. The meaningfulness of these partial mediations are assessed by decomposing the total effects into direct and indirect effects in Table 6. The indirect effect of uncertainty on performance is only 0.032 , which is below the meaningful threshold of 0.05 suggested by Bartol (1983, p.809), however, the indirect effect of complexity of 0.096 is 
above the 0.05 meaningful benchmark. Thus, the overall results suggest that the positive relationship between complexity and innovation performance is partly due to the use of formal controls. Notably, the direct negative association between uncertainty and innovation performance becomes significantly positive after taking into account the use of formal controls. This result suggests that the use of formal controls may play a vital role in reducing uncertainty in inter-firm innovation projects, which could then lead to better innovation performance.

A similar analysis is also conducted for the use of social controls as a mediator on the relationships between the project characteristics and innovation performance. The results indicate a partial mediation of the use of social controls in the relationship between complexity and performance, with an indirect effect of 0.058 , which is above the meaningful threshold of 0.05 . Hence, the total effect on complexity on innovation performance consists of a direct effect $(\beta=0.312, \mathrm{t}=2.621, p<0.01)$ and an indirect effect through the use of both formal and social controls. Therefore, only $\mathrm{H} 4 \mathrm{~b}, \mathrm{H} 4 \mathrm{c}$ and $\mathrm{H} 4 \mathrm{f}$ are supported. The insight gained in the use of formal controls impacting on the negative relationship between uncertainty and performance is noteworthy.

[Insert Table 6 here]

Tests on the moderating effects of control variables on the structural models revealed that inbound innovation projects $(p<0.05, \beta=0.193)$ and innovation projects at the stage of commercialisation and value capture $(p<0.10, \beta=0.190)$ are significantly related to higher innovation performance. The findings also suggest that innovation projects with more equity ownership tend to use more formal controls $(p<0.10, \beta=0.213)$. No significant differences in terms of the results were found for the other control variables. 


\section{Discussion and conclusion}

This study aimed to examine the direct effects of: 1) asset specificity, uncertainty and complexity on the performance of inter-firm innovation projects, and, the use of formal and social controls, and, 2) the use of formal and social controls on the performance of interfirm innovation projects. The indirect (mediating) effects of the use of formal and social controls on the proposed relationships of asset specificity, uncertainty and complexity with the performance of inter-firm innovation projects were also investigated.

The project characteristics of asset specificity, uncertainty and complexity were hypothesized as negatively impacting on inter-firm innovation project performance because of the appropriation and performance risks that they engendered on performance. Our study produced interesting results. Asset specificity was not associated with inter-firm innovation project performance. This finding is contradictory to expectations drawn from transaction cost economics theory. We explain this result by questioning the relevance of the construct of asset specificity at the level of granularity of inter-firm innovation projects. Firstly, whilst asset specificity is relevant at an organizational level resulting in organizational mechanisms to minimize appropriation risks, we propose that at the level of projects, it may not be a foremost concern of team members. Secondly, innovation is about experimentation and creativity, suggesting that knowledge that is used to generate innovation may not necessarily be dedicated to, and, restricted in its use for, an innovation project. Indeed a project could benefit from seemingly disparate human capitals, being brought together and reconfigured to produce innovative solutions to problems. Innovation results in new knowledge, an output which is embodied in a new product or process. The notion of asset specificity, however, is of assets as inputs to an innovation project, which have to be safeguarded. As anticipated, 
uncertainty had a negative association with performance. We interpret this to mean that changes in market/customer requirements could result in innovation project outcomes like a new product or service, or process, becoming irrelevant when the product/service is released to the market, or the process is implemented in an organization. Contrary to our prediction, complexity was positively associated with project performance. In our study, complexity was operationalized as the degree of newness of technology, the level and number of skills, degree of integration and difficulty in assessing development requirements. Our findings are consistent with that of Tatikonda and Rosenthal (2000), where the use of higher levels of new technology results in greater achievement of the innovation performance objectives. Our study also found evidence to indicate that the use of higher levels of skills will generate better innovation outcomes.

The study also found that asset specificity did not impact on the use of formal and social controls. It is plausible that the human capitals and physical assets used for inter-firm innovation projects are shared across many projects. Hence, controls to safeguard these assets are influenced by factors at a firm/aggregate-level instead of those at project level. In other words, the use of shared assets will not have a bearing on the use of specific formal and social controls for the project. Uncertainty impacted on the use of social controls but not on formal controls. In the context of inter-firm innovation projects, it seems that high levels of unpredictability make it very difficult to establish clear specifications, goals and outcomes, which form the basis of the use of formal controls. Hence this study finds some support for Kang et al. (2014) where it was argued that there may be less emphasis on the use of formal controls to manage uncertainty. Notably, we found a contra hypothesis $(\mathrm{H} 2 \mathrm{~d})$ negative association between uncertainty and the use of social controls at the level of innovation projects. Whilst the use of social controls facilitate information sharing to enable parties to make sense of an unpredictable context (Revilla and Knoppen, 2015), it seems that 
in regard to innovation projects, an unpredictable context discourages the use of social controls. We surmise that project teams in our study do not see the value in using social controls to mitigate risks associated with uncertain markets. It is plausible also that whilst relevant for project outcomes, controls may be activated at the organizational level instead to manage negative risks resulting from uncertainty, say by clarifying customer requirements, engaging in further market assessments and the like.

In regard to complexity, the study's results suggest that whilst higher levels of integration and difficulty in assessing development requirements present challenges to positive outcomes, these challenges may be managed and mitigated through the use of both formal and social controls. Our sampled organizations activated both impersonal modes of coordination by rules, procedures, plans and schedules, and more personal and group-based modes of coordination which supports the study by Van de Ven et al. (1976). This finding also supports Dekker (2004) who proposed that a set of sophisticated coordination mechanisms of both formal and social controls should be mobilized. The use of social controls seems particularly relevant in the integration of various skills and assessment of development requirements. We propose to reconcile our findings of a negative association between uncertainty and the use of social controls, and a positive association between complexity and social controls. Whilst managing risks relating to unpredictable market requirements may be done at an organizational level, these requirements are translated at a project level as project development requirements and here they are managed by using both formal and social controls. In regard to social controls, they may be useful in ensuring continued commitment amongst team members (Soutar and McNeil, 1993) through improved communication (Rundquist, 2012) in the face of difficulty in assessing development requirements.

This study also found that formal and social controls each helped firms in attaining 
success in inter-firm innovation projects (Davila, 2005). Inter-firm innovation projects, indeed requires structures and systems to elevate an exchange of knowledge (Christiansen et al., 2013). These findings lend support to assertions by Davila (2005) that different types of controls perform specific roles in helping attain success in inter-firm innovation. The use of a combination of controls would seem more effective in achieving innovation goals than the use of a single type of control (Chen et al., 2009), echoing an observation by Bisbe and Malagueño (2009) that a successful innovation project may depend on the activation of diverse forms of control, to create a complementary fit (also see Ylinen and Gullkvist, 2014; Chen et al., 2009).

The tests for indirect (mediating) role of the use of formal and social controls in the relationships between uncertainty and complexity, and, innovation project performance provide useful insights. The role of formal controls in mitigating the effect of uncertainty on performance indicates that there is a role for formal controls in managing the risks that negatively affect performance. Likewise, the use of both formal and social controls allows cutting-edge technology which may be unfamiliar to team members to be successfully integrated into new processes, products and services. The use of these controls also help facilitate the integration of diverse skill-sets, which are critical to creating innovation. Hence the paradox in inter-firm collaboration in innovation projects could be partly and potentially be resolved by the use of formal and social controls at project level.

Our study also found evidence to support a proposition by Davila et al. (2009) which predicted that the distinct and non-linear stages of the innovation process are salient. In particular, this study found that innovation projects at the stage of commercialisation and value capture demonstrated higher performance. This result is unsurprising given that the elements of uncertainty and complexity impacting on the project would have been most 
likely contained or resolved at this stage of the project. It also indicates that the longer the relationship between the collaborators the higher the likelihood that innovation projects will be successful. On could deduce that longer relationships foster an opportunity to learn how to adapt to and work with a partner resulting in better outcomes. The findings also suggest that innovation projects with more equity ownership tend to use more formal controls. This is interpreted to mean that collaborators in inter-firm innovation projects that have a financial stake in projects tend to resort to the use of formal mechanisms such as contracts and have a stronger focus on outcomes. Test results for the control variables, however, do not support Chiesa et al. (2009) which indicated that radical innovation projects require different practices. In explaining our contradictory findings, it is noteworthy that the aforementioned authors differentiate radical and incremental innovation based on their attendant degree of uncertainty and complexity. These elements are already captured in the constructs of uncertainty and complexity used in this study. Because radical innovation projects are typically characterized by an elevated level of uncertainty in their early stage, then our results support Chiesa et al.'s (2009) findings that firms will resort to the use of social controls. Thus in future research, it may be useful to focus also if not, on the degrees of uncertainty and complexity in innovation projects rather than the types and stages of innovation.

Overall, the study contributed to our understanding of how asset specificity, uncertainty and complexity impact on inter-firm innovation project performance. Earlier in the paper, it was indicated that risks engendered by high levels of asset specificity, uncertainty and complexity may be managed at different levels of organizations. At project level, our study found that uncertainty and complexity were relevant to project outcomes. Consequently, the use of formal and social controls was dependent on factors that directly impacted and were subject to some degree of influence by team members. Formal and social controls play 
distinctive roles in managing complexity in these projects. In response to JanowiczPanjaitan and colleagues (2009), this study does not align with their view that inter-firm innovation projects will necessarily require more interpersonal and less formal processes of coordination, instead suggesting that they are used complementarily.

The findings of this study, however, are subject to at least three limitations which could be addressed in future research. The first limitation relates to the biases that respondents may have had, the size of the sample of respondents and endogeneity of the constructs. Whilst precautionary steps were made to limit social desirability bias, there is still the possibility of this bias. Despite encouraging results from tests for common method bias and the use of single respondents to represent inter-firm projects (see Revilla and Knoppen, 2015), there could still be this bias in the data. In future responses from dyads will help redress this issue. The sample size of 75 observations of Australian inter-firm innovation projects may mean that the study should be replicated in other settings for the findings to be empirical generalizable. However, the study's findings may have theoretical generalizability given the literature on the role of risks in performance and the use of formal and social controls, and, the role of the use of controls in performance. The cross-sectional nature of the data means that causal relationships amongst the variables cannot be supported. To support causal relationships, a future study using the case study or experimental method, would be useful. 


\section{Questionnaire items}

\section{Appendix}

Asset specificity (AS)

Degree to which the following investments dedicated to this inter-firm innovation could be redeployed to other innovation projects or company transactions:

AS1 Human capital (e.g. training, knowledge) (R)*.

AS2 Brand name capital (R)*.

AS3 Equipment and other physical assets (R)*.

AS4 Site or facilities (R)*.

AS5 Tailored procedures and routines $(\mathrm{R})^{*}$.

AS6 Overall, the degree to which investments dedicated to the inter-firm innovation could be redeployed is $(\mathrm{R})^{*}$.

*Items marked (R) are reversed. Overall item is excluded from structural model analysis.

\section{Uncertainty (UNT)}

Ability of our company to:

UNT1 Accurately forecast the technical requirements/changes in this innovation (R)*.

UNT2 Verify whether compliance with established agreements will occur in this inter-firm innovation $(\mathrm{R})^{*}$.

UNT3 Predict potential cost/benefit ratio for this innovation (R)*.

UNT4 Anticipate competitors' reactions to this innovation (R)*.

UNT5 Anticipate changes in market needs (R)*.

UNT6 Anticipate other industry changes (e.g. regulatory requirements) (R)*.

UNT7 Overall, the ability of our company to predict the relevant contingencies relating to this interfirm innovation is $(\mathrm{R})^{*}$.

*Items marked (R) are reversed.

\section{Complexity (CMX)}

CMX1 Degree of the newness of the technology.

CMX2 The number of skills or functions involved.

CMX3 The level of skills or functions required.

CMX4 The extent of interactions among the different skills or functions.

CMX5 The extent of integration of different research and development decisions.

CMX6 Difficulty in assessing development process requirements.

CMX7 Overall, the level of complexity of this innovation is.

The extent to which YOUR COMPANY use the following mechanisms in this inter-firm innovation

Formal controls (FC)

FC1 Contracts

FC2 Planning and budgeting

FC3 Standardised procedures and rules.

FC4 Formal project methodology (e.g. PRINCE2, PIMBOK, AGILE, SCRUM). 
FC5 Performance evaluation.

FC6 Structural grouping and departmentalisation.

FC7 Management reports.

Social controls $(\mathrm{SC})$

SC1 Networking and other socialization processes.

SC2 Teams and taskforces.

SC3 Transfer of managers/lateral movements.

SC4 Rituals, traditions and ceremonies.

SC5 Organisational culture/values alignment.

SC6 Ad-hoc committees.

SC7 Face-to-face communication.

SC8 Participatory decision-making.

Innovation project performance (PER)

The degree to which, at the current stage of this inter-firm innovation:

PER1 Our company has achieved its primary objective(s).

PER2 Our company's competitive position has been greatly enhanced because of this innovation.

PER3 Our company has been successful in learning some critical technologies, skills or capabilities from this innovation partner.

PER4 Compared to competitors, our company exhibits a higher level of innovation performance.

PER5 Overall, our company is satisfied with the performance of this inter-firm innovation. 


\begin{tabular}{llll}
\hline & & Frequency & Per cent \\
\hline Position & Top Management & 50 & 66 \\
& Functional Management & 23 & 31 \\
\multirow{3}{*}{ Working Experience } & Other & 2 & 3 \\
& <3 years & 10 & 13 \\
& 3-10 years & 16 & 21 \\
Gender & >10 years & 49 & 65 \\
& Male & 62 & 83 \\
& Female & 13 & 17 \\
\hline
\end{tabular}

Table 1. Profile of respondents.

\begin{tabular}{|c|c|c|c|}
\hline & & Frequency & Per cent \\
\hline \multirow[t]{6}{*}{ Sector } & Manufacturing & 32 & 42.7 \\
\hline & Information media and telecommunications & 12 & 16.0 \\
\hline & Professional, scientific and technical services & 12 & 16.0 \\
\hline & Retail trade & 9 & 12.0 \\
\hline & Other & 8 & 10.7 \\
\hline & Wholesale trade & 2 & 2.7 \\
\hline \multirow[t]{3}{*}{ Employee } & Up to 50 & 11 & 14.7 \\
\hline & $51-1,000$ & 53 & 70.7 \\
\hline & More than 1,000 & 11 & 14.7 \\
\hline \multirow[t]{3}{*}{ Revenue } & Up to $\$ 1$ million & 2 & 2.7 \\
\hline & $\$ 1-\$ 25$ million & 28 & 37.3 \\
\hline & More than $\$ 25$ million & 43 & 57.3 \\
\hline \multirow[t]{3}{*}{ Assets } & Up to $\$ 1$ million & 5 & 6.7 \\
\hline & $\$ 1-\$ 12.5$ million & 28 & 37.3 \\
\hline & More than $\$ 12.5$ million & 41 & 54.7 \\
\hline \multirow{5}{*}{ Nature of innovation } & Goods and Services Innovation & 30 & 40.0 \\
\hline & $\begin{array}{l}\text { Organizational/Managerial Processes } \\
\text { Innovation }\end{array}$ & 10 & 13.3 \\
\hline & Operational Processes Innovation & 21 & 28.0 \\
\hline & Marketing Methods Innovation & 10 & 13.3 \\
\hline & Other & 4 & 5.3 \\
\hline \multirow[t]{2}{*}{ Degree of innovation } & Incremental & 62 & 82.7 \\
\hline & Radical & 13 & 17.3 \\
\hline \multirow{6}{*}{ Stage of innovation } & Intelligence gathering & 5 & 6.7 \\
\hline & Idea recognition and selection & 5 & 6.7 \\
\hline & Execution & 23 & 30.7 \\
\hline & Transition to operations & 15 & 20.0 \\
\hline & Commercialization and value capture & 23 & 30.7 \\
\hline & Other & 4 & 5.3 \\
\hline \multirow[t]{2}{*}{ Previous Experience } & Yes & 31 & 41.3 \\
\hline & No & 43 & 57.3 \\
\hline \multirow[t]{4}{*}{ Ownership } & No equity & 50 & 66.7 \\
\hline & Less than $50 \%$ equity & 5 & 6.7 \\
\hline & $50 \%$ equity & 5 & 6.7 \\
\hline & More than $50 \%$ equity & 15 & 20.0 \\
\hline
\end{tabular}

Table 2. Information relating to the Sample of Inter-firm Innovation Projects. 


\begin{tabular}{|c|c|c|c|c|c|c|c|}
\hline & Mean & $\begin{array}{l}\text { Standard } \\
\text { deviation }\end{array}$ & $\begin{array}{l}\text { Factor } \\
\text { loadings }\end{array}$ & t-Statistic $\mathbf{a}^{\mathbf{a}}$ & $\begin{array}{l}\text { Cronbach } \\
\text { alpha }(\alpha)\end{array}$ & $\begin{array}{l}\text { Composite } \\
\text { reliability }\end{array}$ & $\begin{array}{c}\text { Average } \\
\text { variance } \\
\text { extracted } \\
\text { (AVE) }\end{array}$ \\
\hline \multicolumn{5}{|l|}{ Assets Specificity } & 0.772 & 0.839 & 0.593 \\
\hline AS1 & 3.01 & 1.48 & 0.623 & 5.852 & & & \\
\hline AS2 & 4.67 & 1.83 & 0.599 & 6.079 & & & \\
\hline AS3 & 4.40 & 1.83 & 0.707 & 9.031 & & & \\
\hline AS4 & 4.41 & 1.90 & 0.746 & 11.240 & & & \\
\hline AS5 & 3.38 & 1.48 & 0.573 & 6.356 & & & \\
\hline \multicolumn{5}{|l|}{ Uncertainty } & 0.903 & 0.924 & 0.635 \\
\hline UNT1 & 3.53 & 1.35 & 0.730 & 13.225 & & & \\
\hline UNT2 & 3.12 & 1.45 & 0.803 & 21.766 & & & \\
\hline UNT3 & 3.32 & 1.40 & 0.796 & 16.118 & & & \\
\hline UNT4 & 3.78 & 1.47 & 0.728 & 10.303 & & & \\
\hline UNT5 & 3.38 & 1.31 & 0.842 & 21.320 & & & \\
\hline UNT6 & 3.69 & 1.41 & 0.750 & 11.895 & & & \\
\hline \multicolumn{5}{|l|}{ Complexity } & 0.915 & 0.933 & 0.665 \\
\hline CMX1 & 4.37 & 1.51 & 0.804 & 17.972 & & & \\
\hline CMX2 & 4.67 & 1.45 & 0.835 & 15.860 & & & \\
\hline CMX3 & 4.73 & 1.34 & 0.819 & 12.861 & & & \\
\hline CMX4 & 4.77 & 1.18 & 0.799 & 9.932 & & & \\
\hline CMX5 & 4.68 & 1.36 & 0.783 & 16.970 & & & \\
\hline CMX6 & 4.40 & 1.16 & 0.728 & 10.590 & & & \\
\hline \multicolumn{5}{|c|}{ Innovation performance } & 0.918 & 0.939 & 0.755 \\
\hline PER1 & 4.85 & 1.45 & 0.857 & 23.530 & & & \\
\hline PER2 & 4.77 & 1.48 & 0.862 & 25.201 & & & \\
\hline PER3 & 5.17 & 1.32 & 0.811 & 16.438 & & & \\
\hline PER4 & 4.93 & 1.53 & 0.870 & 26.652 & & & \\
\hline
\end{tabular}

Table 3. Factor loadings and reliability test results for reflective constructs. 


\begin{tabular}{lcccc}
\hline & AS & UNT & CMX & PER \\
\hline AS1 & $\mathbf{0 . 6 2 3}$ & 0.389 & -0.349 & -0.321 \\
AS2 & $\mathbf{0 . 5 9 9}$ & 0.250 & -0.221 & -0.348 \\
AS3 & $\mathbf{0 . 7 0 7}$ & 0.411 & -0.385 & -0.374 \\
AS4 & $\mathbf{0 . 7 4 6}$ & 0.473 & -0.397 & -0.365 \\
AS5 & $\mathbf{0 . 5 7 3}$ & 0.373 & -0.186 & -0.297 \\
UNT1 & 0.463 & $\mathbf{0 . 7 3 0}$ & -0.535 & -0.538 \\
UNT2 & 0.537 & $\mathbf{0 . 8 0 3}$ & -0.455 & -0.561 \\
UNT3 & 0.430 & $\mathbf{0 . 7 9 6}$ & -0.438 & -0.496 \\
UNT4 & 0.482 & $\mathbf{0 . 7 2 8}$ & -0.435 & -0.479 \\
UNT5 & 0.507 & $\mathbf{0 . 8 4 2}$ & -0.498 & -0.509 \\
UNT6 & 0.329 & $\mathbf{0 . 7 5 0}$ & -0.294 & -0.365 \\
CMX1 & -0.384 & -0.485 & $\mathbf{0 . 8 0 4}$ & 0.606 \\
CMX2 & -0.415 & -0.456 & $\mathbf{0 . 8 3 5}$ & 0.528 \\
CMX3 & -0.366 & -0.500 & $\mathbf{0 . 8 1 9}$ & 0.467 \\
CMX4 & -0.338 & -0.452 & $\mathbf{0 . 7 9 9}$ & 0.522 \\
CMX5 & -0.372 & -0.460 & $\mathbf{0 . 7 8 3}$ & 0.501 \\
CMX6 & -0.398 & -0.315 & $\mathbf{0 . 7 2 8}$ & 0.389 \\
PER1 & -0.469 & -0.503 & 0.496 & $\mathbf{0 . 8 5 7}$ \\
PER2 & -0.515 & -0.611 & 0.640 & $\mathbf{0 . 8 6 2}$ \\
PER3 & -0.407 & -0.508 & 0.543 & $\mathbf{0 . 8 1 1}$ \\
PER4 & -0.390 & -0.518 & 0.529 & $\mathbf{0 . 8 7 0}$ \\
\hline AS = assets specificity & UNT $=$ uncertainty, CMX complexity, PER & innovation \\
performance. & & & & \\
\hline & & & & \\
\hline
\end{tabular}

Table 4. Discriminant validity test - cross factor loadings.

\begin{tabular}{lcccc}
\hline & AS & UNT & CMX & PER \\
\hline AS & $\mathbf{0 . 6 9 0}$ & & & \\
UNT & 0.599 & $\mathbf{0 . 7 9 7}$ & & \\
CMX & 0.558 & 0.558 & $\mathbf{0 . 8 1 5}$ & \\
PER & 0.638 & 0.636 & 0.636 & $\mathbf{0 . 8 6 9}$ \\
\hline
\end{tabular}

AS = asset specificity, UNT = uncertainty, CMX = complexity, PER = innovation performance.

Numbers in bold $=$ square roots of AVEs of constructs.

Table 5. Discriminant validity: construct correlations and square root of average variance extracted (AVE). 
Table 6 Standardized Direct, Indirect and Total Effects (H4)

\begin{tabular}{|c|c|c|c|}
\hline Relationships & $\begin{array}{l}\text { Standardized } \\
\text { Direct Effects }\end{array}$ & $\begin{array}{c}\text { Standardized } \\
\text { Indirect Effects }\end{array}$ & $\begin{array}{l}\text { Standardized } \\
\text { Total Effects } \\
\end{array}$ \\
\hline Assets Specificity -Formal Control - Innovation performance & $0.096(0.701)$ & $-0.009(0.634)$ & $0.087(0.556)$ \\
\hline Uncertainty -Formal Control - Innovation performance & $0.319(2.314 *)$ & $0.032(0.662)$ & $0.351(2.661 * *)$ \\
\hline Complexity -Formal Control - Innovation performance & $0.257(2.065 *)$ & $0.096(1.255)$ & $0.353(2.904 * *)$ \\
\hline Assets Specificity - Social Controls- Innovation performance & $0.062(0.439)$ & $0.031(0.474)$ & $0.093(0.624)$ \\
\hline Uncertainty - Social Controls- Innovation performance & $0.258(1.777)$ & $0.074(1.440)$ & $0.332(0.560)$ \\
\hline Complexity - Social Controls - Innovation performance & $0.312(2.621 * *)$ & $0.058(0.950)$ & $0.371(2.894 * *)$ \\
\hline $\begin{array}{l}\text { All values are standardized coefficients with } p \text { value in parentheses. } \\
* \text { Significant at } p<0.05 \text { (two-tailed). } \\
* * \text { Significant at } p<0.01 \text { (two-tailed). }\end{array}$ & & & \\
\hline
\end{tabular}

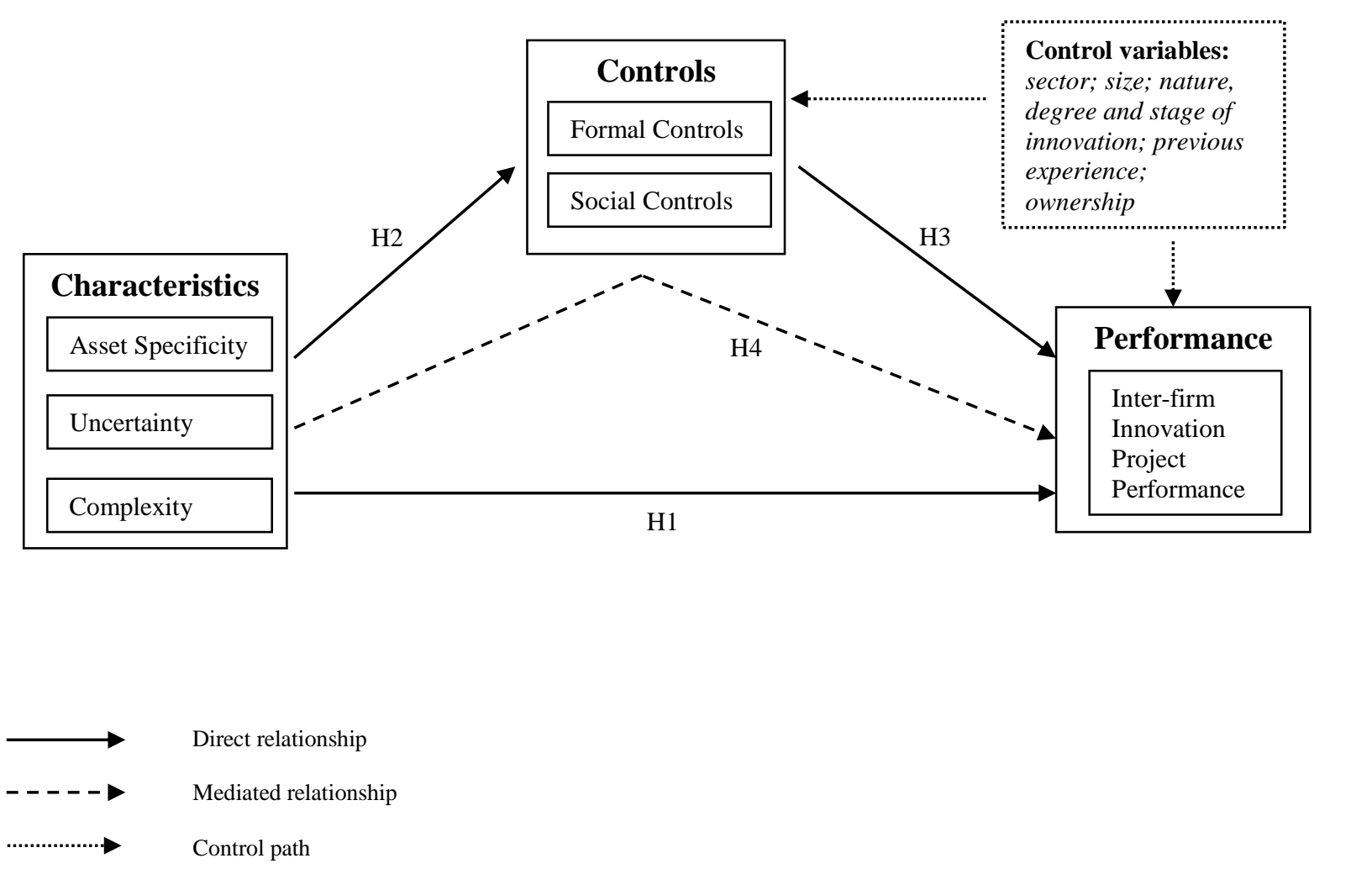

Fig. 1. Conceptual model. 


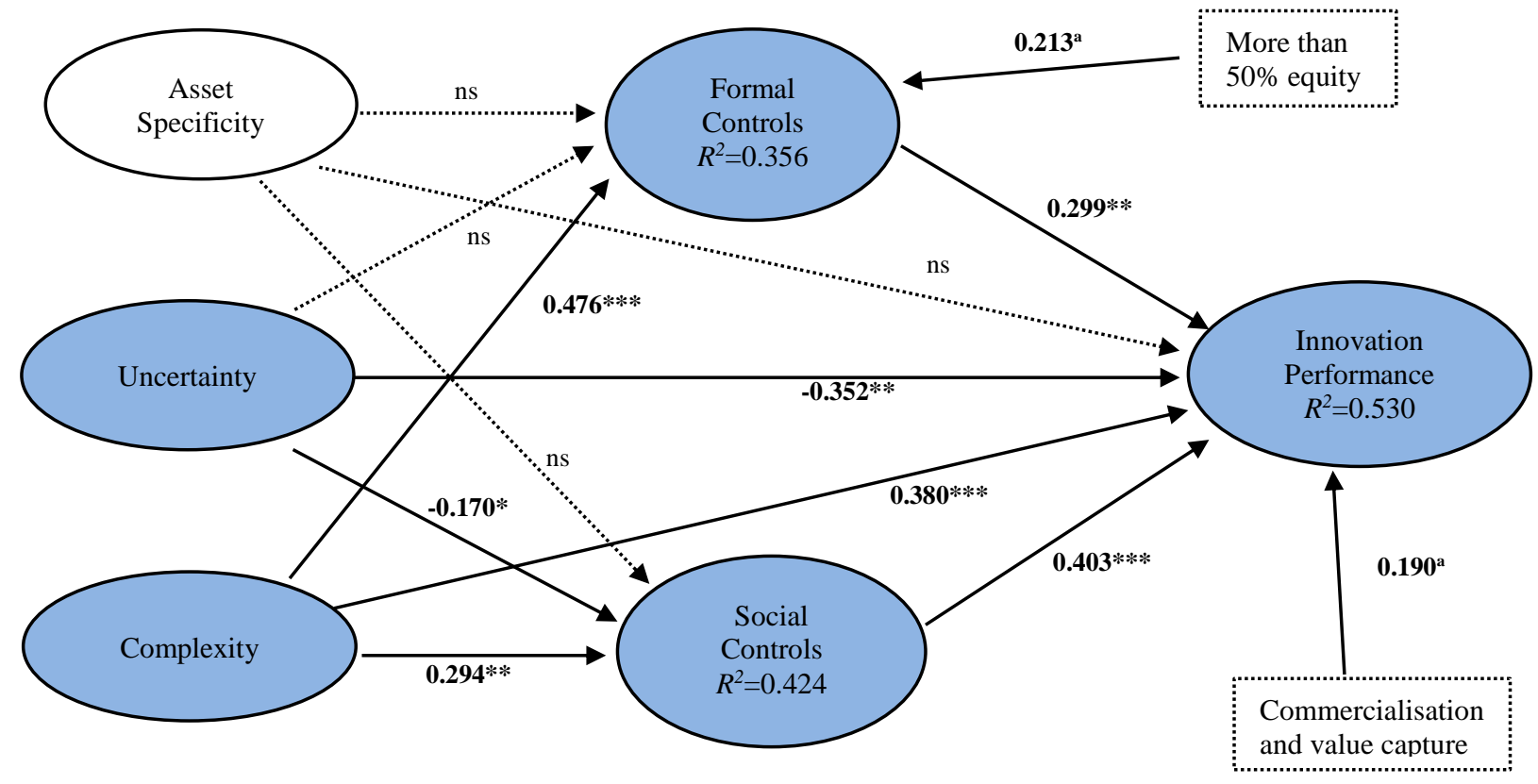

ns: not significant, $*$ significant at $p<0.05, * *$ significant at $p<0.01, * * *$ significant at $p<0.001$.

a significance level of $p<0.10$ (two-tailed test).

Fig. 2. PLS results. 


\section{References}

Abernethy, MA and Brownell, P (1997). Management control systems in research and development organizations: the role of accounting, behavior and personnel controls. Accounting, Organizations and Society, 22(3/4), 233-248.

Amabile, TM (1998). How to kill creativity. Harvard Business Review, 76(5), 76-87.

Anderson SW and Dekker, HC, (2009). Strategic Cost Management in Supply Chains, Part 1: Structural Cost Management, Accounting Horizons, 23(2), 201-220.

Anthony, R, J Dearden, and NM Bedford (1989). Management Control Systems (6th Edition). Homewood, III: Irwin.

Australian Bureau of Statistics (ABS). (2013). "2010-11 Innovation in Australian Business Survey (IABS)”, Commonwealth of Australia, Canberra, http://www.abs.gov.au/AUSSTATS/abs@.nsf/Latestproducts/8DEB44FC1970F14CCA257A6200136 AB0?opendocument>. accessed on 08 April, 2013.

Baraldi, E and Strömsten, T (2009). Controlling and combining resources in networks - from Uppsala to Stanford, and back again: The case of a biotech innovation. Industrial Marketing Management, 38(5), 541-552.

Baragheh, A, J Rowley and S Sambrook (2009). Towards a multidisciplinary definition of innovation. Management Decision, 47(8), 1323-1339.

Baron, R. M., and Kenny, D. A. (1986). The moderator-mediator variable distinction in social psychological research: conceptual, strategic, and statistical considerations. Journal of Personality and Social Psychology, 51(6), 1173-1182.

Bharadwaj, S and Menon, A (2000). Making innovation happen in organizations: individual creativity mechanisms, organizational creativity mechanisms or both?. Journal of Product Innovation Management, 17(6), 424-434.

Bigliardi, B, E Bottani and F Galati (2010). Open innovation and supply chain management in food machinery supply chain: a case study. International Journal of Engineering, Science and Technology, 2(6), 244-255.

Bisbe, J, J Batistafoguet and R Chenhall (2007). Defining management accounting constructs: A methodological note on the risks of conceptual misspecification. Accounting, Organizations and Society, 32(7-8), 789-820.

Bisbe, J and Malagueño, R (2009). The Choice of Interactive Control Systems under Different Innovation Management Modes. European Accounting Review, 18(2), 371-405.

Bisbe, J and Otley, D (2004). The effects of the interactive use of management control systems on product innovation. Accounting, Organizations and Society, 29(8), 709-737.

Borys, B and Jemison, DB (1989). Hybrid arrangements as strategic alliances: theoretical issues in organizational combinations. Academy of Management Review, 14(2), 234-249.

Bouncken, RB and Fredrech, V (2012). Coopetition: Performance Implications and Management Antecedents. International Journal of Innovation Management, 16(5), 1250028-1 - 1250028-28.

Burns, T and Stalker, G (1961). The Management of Innovation. Tavistock.

Carbonell, P and Rodriguez, AI (2006). Designing teams for speedy product development: the moderating effect of techonology complexity. Journal of Business Research, 59(2), 225-232.

Chalos, P and O'Connor, NG (2004). Determinants of the use of various control mechanisms in US-Chinese joint ventures. Accounting, Organizations and Society, 29(7), 591-608.

Chapman, CS (1997). Reflections on a contingent view of accounting. Accounting, Organizations and Society, 22(2), 189-205.

Chapman, R and Hyland, P (2004). Complexity and learning behaviors in product innovation. Technovation, 24(7), 553-561.

Chen, D, S Park, and W Newburry (2009). Parent contribution and organizational control in international joint ventures. Strategic Management Journal, 30(11), 1133-1156.

Chenhall, RH (2006). Theorizing Contingencies in Management Control Systems Research, In CS Chapman, AG Hopwood and MD Shields (Eds.) Handbook of Management Accounting Research. Elsevier.

Chenhall, RH and Morris, D (1995). Organic decision and communication processes and management accounting systems in entrepreneurial and conservative business organizations. Omega, 23(5), $485-497$. 
Chesbrough, H (2003). Open innovation - The new imperative for creating and profiting from technology. Harvard Business School Press, Boston (MA).

Chiesa, V, F Frattini, L Lamerti and G Noci (2009). Exploring management control in radical innovation projects. European Journal of Innovation Management, 12(4), 416-443.

Chin, WW (1998). Issues and opinion on structural equation modeling. MIS Quarterly, 22(1), 7-16.

Christiansen, JK, M Gasparin, and CJ Varnes (2013). Improving Design with Open Innovation: A Flexible Management Technology. Research - Technology Management, 56(2), 36-44.

Crossan, MM and Inkpen, AC (1995). The subtle art of learning through alliances. Business Quarterly, Winter, 6978.

Das, TK and Teng, B-S (2001). Trust, Control, and Risk in Strategic Alliances: An Integrated Framework. Organization Studies, 22(2), 251-283.

Davila, T (2000). An empirical study on the drivers of management control systems design in new product development. Accounting, Organizations and Society, 25(4/5), 383-409.

Davila, A (2005). An exploratory study on the emergence of management control systems design in new product development. Accounting, Organizations and Society, 30(3), 223-248.

Davila, A, G Foster, and D Oyon (2009). Accounting and Control, Entrepreneurship and Innovation: Venturing into New Research Opportunities. European Accounting Review, 18(2), 281-311.

Davis, JM, C Mora-Monge, G Quesada and M Gonzalez (2014). Cross-cultural influences on e-value creation in supply chains. Supply Chain Management: An International Journal, 19(2), 187-199.

Dekker, HC (2004). Control of inter-organizational relationships: evidence on appropriation concerns and coordination requirements. Accounting, Organizations and Society, 29(1), 27-49.

Dekker, HC (2008). Partner selection and governance design in inter-firm relationships. Accounting, Organizations and Society, 33(7-8), 915-941.

Dekker, HC, J Sakaguchi and T Kawai (2013). Beyond the contract: Managing risk in supply chain relations. Management Accounting Research, 24(2), 122-139.

Ding, R, HC Dekker, and T Groot (2013). Risk, partner selection and contractual control in interfirm relationships. Management Accounting Research, 24(2), 140-155.

Ditillo, A (2004). Dealing with uncertainty in knowledge-intensive firms: the role of management control systems as knowledge integration mechanisms. Accounting, Organizations and Society, 29(3-4), 401-421.

Dodgson, M, DM Gann, and A Salter (2002). The intensification of innovation. International Journal of Innovation Management, 6(1), 53-83.

Dougherty, D and Hardy, C (1996). Sustained product-innovation in large-mature organisations: Overcoming innovation-to-organisation problems. Academy of Management Journal, 39(5), 1120-1153.

Dowling, C (2009). Appropriate Audit Support System Use: The Influence of Auditor, Audit Team, and Firm Factors. The Accounting Review, 84(3), 771-810.

Ezzamel, M (1990). The impact of environmental uncertainty, managerial autonomy, and size on budget characteristics. Management Accounting Research, 1(3), 181-197.

Finch, D., O'Reilly, N., Hillenbrand, C. and Abeza, G.( 2015). Standing on the Shoulders of Giants: An Examination of the Interdisciplinary Foundation of Relationship Marketing. Journal of Relationship Marketing, 14, 171-196.

Galbraith, J (1973). Designing complex organizations. Addison Wesley Publishing Company.

Gassmann, 0 (2006). Opening up the innovation process: Towards an agenda. R\&D Management, 36(3), 223-228.

Gefen, D and Straub, D (2005). A practical guide to factorial validity using PLS-Graph: tutorial and annotated example. Communications of the AIS, 19, 91-109.

Geyskens, I, JBEM Steenkamp and N Kumar (2006). Make, buy, or ally: a transaction cost theory metaanalysis. Academy of Management Journal, 49(3), 519-543.

Giacobbe, F and Booth, P (2009). Controlling International Joint Ventures: An Investigation of Australian Parent Partners. Australian Accounting Review, 19(2), 103-116.

Gordon, LA and Narayanan, VK (1984). Management accounting systems, perceived environmental uncertainty and organizational structure: an empirical investigation. Accounting, Organizations and Society, 9(1), 33-47.

Griffin, A (1997). The effect of project and process characteristics on product development cycle time. Journal of Marketing Research, 34(1), 24-35. 
Gulati, R and Singh, H (1998). The architecture of cooperation: managing coordination costs and appropriation concerns in strategic alliances. Administrative Science Quarterly, 43(4), 781-814.

Hansen, A and Jönsson, S (2005). Target costing and coordination - Framing cost information sharing in new product development, In S Jönsson and J Mouritsen (Eds.) Accounting in Scandinavia - The northern lights. Liber and Copenhagen Business School Press.

Hartmann, F and Slapničar, S (2009). How formal performance evaluation affects trust between superior and subordinate managers. Accounting, Organizations and Society, 34(6-7), 722-737.

Haustein, E, R Luther, and P Schuster (2014). Management control systems in innovation companies: a literature based framework. Journal of Management Control, 24(4), 343-382.

Heide, JB and John, G (1990). Alliances in industrial purchasing: The determinants of joint action in buyersupplier relationships. Journal of Marketing Research, 27(1), 24-36.

Hoecht, A and Trott, P (2006). Innovation risks of strategic outsourcing. Technovation, 26(5-6), 672-681.

Hopwood, AG (1976). Accounting and Human Behavior. Englewood Cliffs, NJ: Prentice-Hall.

Kamminga, PE and van der Meer-Kooistra, J (2007). Management control patterns in joint venture relationships: a model and an exploratory study. Accounting, Organizations and Society, 32(1/2), 131154.

Kang, M, X Wu, P Hong, K Park, and Y Park (2014). The role of organizational control in outsourcing practices: An empirical study. Journal of Purchasing and Supply Management, 20(3), 177-185.

Kerssens-van Drongelen, IC and Bilderbeek, J (2009). R\&D performance measurement: more than choosing a set of metrics. $R \& D$ Management, 29(1), 35-46.

Kim, J and Wilemon, D (2003). Sources and assessment of complexity in NPD projects. R\&D Management, 33(1), 15-30.

Kirsch, LS (1997). Portfolios of control modes and IS project management. Information Systems Research, 8(3), 215-239.

Langfield-Smith, K (2008). The relations between transactional characteristics, trust and risk in the start-up phase of a collaborative alliance. Management Accounting Research, 19(4), 344-364.

Langfield-Smith, K and Smith, D (2003). Management control systems and trust in outsourcing relationships. Management Accounting Research, 14(3), 281-307.

Lau, CM and Roopnarain, K (2014). The effects of nonfinancial and financial measures on employee motivation to participate in target setting. The British Accounting Review, 46(3), 228-247.

Lawrence, $\mathrm{P}$ and Lorsch, J (1967). Organization and Environment. Irwin.

Li, Y, F Ye, and C Sheu (2014). Social capital, information sharing and performance: Evidence from China. International Journal of Operations and Production Management, 34(11), 1440-1462.

Lichtenthaler, U (2008). Integrated Roadmaps for Open Innovation. Research Technology Management, 51(3), 4549.

Luo, Y (2008). Procedural fairness and interfirm cooperation in strategic alliances. Strategic Management Journal, 29(1), 27-46.

Mahama, H (2006). Management control systems, cooperation and performance in strategic supply relationships: a survey in the mines. Management Accounting Research, 17(3), 315-339.

McCarthy, IP and BR Gordon (2011). Achieving contextual ambidexterity in R\&D organizations; a management control approach. $R \& D$ Management, 41(3), 240-258.

Merchant, K A (1985). Control in Business Organizations. Pitman, Boston.

Merchant, K and Otley, D (2007). A review of the literature on control and accountability. In Chapman, C.S. Hopwood, A. and Shields, M. (Eds), The Handbook of Management Accounting Research, Elsevier, Oxford, pp. 785-806

Meyer, MH and Utterback, JM (1995). Product development cycle time and commercial success. IEEE Transactions on Engineering Management, 42, 297-304.

Miller, PB, JL Moll, and T O’Leary (2011). Managing inter-firm interdependencies in R\&D investment: Insights from the semiconductor industry. Chartered Institute of Management Accountants (CIMA), <http://www.cimaglobal.com/Documents/Thought_leadership_docs/ Organizational\%20management/RD-invest-report.pdf>. accessed on $31 \mathrm{March}, 2013$.

Mohr, JJ and Sengupta, S (2005). Managing the paradox of inter-firm learning: the role of governance mechanisms. Journal of Business and Industrial Marketing, 17(4), 282-301.

Mouritsen, J, A Hansen and CO Hansen (2009). Short and long translations: Management accounting calculations 
and innovation management. Accounting, Organizations and Society, 34(6-7), 738-754.

Nooteboom, B (2004.) Inter-firm Collaboration, Learning and Networks. Routledge, London.

Ouchi, WG (1977). The Relationship between Organizational Structures and Organizational Control. Administrative Science Quarterly, 22(1), 95-1 12.

Ouchi, WG (1979) A Conceptual Framework for the Design of Organizational Control Mechanisms. Management Science, 25 (9), 833-849.

Otley, DT and Berry, AJ (1994). Case study research in management accounting and control. Management Accounting Research, 5(1), 45-65.

Otley, D, J Broadbent, and AJ Berry (1995). Research in Management Control: An Overview of its Development. British Journal of Management, 6, S1, S31-S44.

Perrow, C (1970). Organizational analysis: a sociological review. Wadsworth Publishing Company.

Petter, S, D Straub, and A Rai (2007). Specifying formative constructs in information systems research. MIS Quarterly, 31(4), 623-656.

Revilla, E and Knoppen, D (2015). Building knowledge integration in buyer-supplier relationships: The critical role of strategic supply management and trust. International Journal of Operations and Production Management, 35(10), 1408-1436.

Ringle, CM, S Wende, JM Becker (2015). Smartpls 3, Boenningsted: SmartPLS GmbH, Retrieved from http://www.smartpls.com.

Rosell, DT (2014). Implementation of Open Innovation Strategies: A Buyer-Supplier Perspective. International Journal of Innovation Management, 18(6), DOI: 10.1142/S1363919614400131

Rundquist, J (2012). The ability to integrate different types of knowledge and its effect on innovation performance. International Journal of Innovation Management, 16(2), 1-32.

Simonin, BL (1997). The importance of collaborative know-how: an empirical test of the learning organization. Academy of Management Journal, 40(5), 1150-1174.

Simons, R (1987). Accounting control systems and business strategy: an empirical analysis. Accounting, Organizations and Society, 12(4), 357-375.

Simons, R (1995). Levers of control. Harvard Business School Press, Boston.

Smets, LPM, F Langerak, and MV Tatikonda (2016). Collaboration between competitors' NPD teams; in search of effective modes of management control. R\&D Management, 46(1), 244-260.

Soutar, GN and MM McNeil (2008). Corporate Innovation: Some Australian Experiences. Prometheus: Critical Studies in Innovation, 11(2), 200-218.

Speklé, RF (2001). Explaining management control structure variety: a transaction cost economics perspective. Accounting, Organizations and Society, 26(4-5), 419-441.

Tainter, JA (1988). The Collapse of Complex Societies, Cambridge University Press, Cambridge, UK.

Thompson, JD (1967). Organizations in action. McGraw Hill.

Triguero, A and Córcoles, D (2013). Understanding innovation: An analysis of persistence for Spanish manufacturing firms. Research Policy, 42(2), 340-352.

Van de Ven, AH, AL Delbecq, and RJr Koenig (1976). Determinants of coordination modes within organizations. American Sociological Review, 41(2), 322-338.

Van De Vrande, V, PJ De Jong, W Vanhaverbeke and M De Rochemont (2009). Open Innovation in SMEs: Trends, Motives and Management Challenges. Technovation, 29(6-7), 423-437.

Van der Meer-Kooistra, J and Scapens, RW (2008). The governance of lateral relations between and within organizations. Management Accounting Research, 19(4), 365-384.

Van der Meer-Kooistra, J and Scapens, RW (2015). Governing product co-development projects: The role of minimal structures. Management Accounting Research, 28, 68-91.

Van der Meer-Kooistra, J and Vosselman, EGJ (2000). Management control of inter-firm transactional relationships: the case of industrial renovation and maintenance. Accounting, Organizations and Society 25(1), 51-77.

Vélez, ML JM Sánchez, and C lvarez-Dardet, C (2008). Management control systems as interorganizational trust builders in evolving relationships: Evidence from a longitudinal case study. Accounting, Organizations and Society, 33(7-8), 968-994.

Verona, G (1999). A resource-based view of product development. Academy of Management Review, 24(1), 132142.

Walter, J, C Lechner, and FW Kellermanns (2008). Disentangling Alliance Management Processes: 
Decision Making, Politicality, and Alliance Performance. Journal of Management Studies, 45(3), 530560.

Wilkins, AL and Ouchi, WG (1983). Efficient cultures: exploring the relationship between culture and organizational performance. Administrative Science Quarterly, 28(3), 468-481.

Williamson, O (1991). Comparative economic organization: the analysis of discrete structural alternatives. Administrative Science Quarterly, 36(2), 269-296.

Ylinen, $\mathrm{M}$ and Gullkvist, B (2014). The effects of organic and mechanistic control in exploratory and exploitative innovations. Management Accounting Research, 25(1), 93-112.

Zhao, R (2003). Transition in R \& D management control system: case study of a biotechnology institute in China. Journal of High Technology, 14(4), 213-229. 